\title{
Isolation and identification of elite phosphate solubilizing bacteria from soil under paddy cultivation
}

\author{
A. Gandhi, G. Muralidharan, E. Sudhakar \\ Botany wing - DDE, Annamalai University, Annamalainagar - 608 002, Tamil Nadu, India \\ E-mail address: drgbot@gmail.com
}

\begin{abstract}
A considerable number of bacterial species are able to exert a beneficial effect upon plant growth. Mostly they are associated with the plant rhizosphere, so they are called as rhizobacteria. Phosphorus is an essential element for plant development and growth making up about $0.2 \%$ of plant dry weight. Several scientists have reported the ability of different bacterial species to solubilize insoluble inorganic phosphate compounds, such as tricalcium phosphate, dicalcium phosphate, hydroxyapatite, and rock phosphate. Detection and estimation of the phosphate solublization ability of microorganisms have been possible using plate screening methods. Phosphate solubilizers produce clearing zones around the microbial colonies in growth media. In the present investigation a total number of fifteen phosphate solubilizing bacterial colonies isolated from different paddy soils in Cuddalore district of Tamilnadu, India. The isolated PSB were identified and characterized for effective use in the field. All the PSB isolates were identified as Bacillus species and designated as P with serial number from 1 to 15 . Among the fifteen isolates, the PSB isolate P6 showed highest amount of phosphate solubilization. The quantity of available phosphorus estimated in the P6 grown Sperber broth culture medium on $7^{\text {th }}$ day was maximum of $321.7 \mu \mathrm{g} / \mathrm{ml}$ which was the highest value compared to other PSB isolates.
\end{abstract}

Keywords: Rhizobacteria; Phosphate Solubilizing Bacteria; PSB; Bacillus; Tricalcium phosphate

\section{INTRODUCTION}

Phosphorous is major essential element for growth and development of plants compared with all other minerals. It plays a crucial role in major physiological activities of plants such as cell division, photosynthesis, and development of good root system. Scarcity of phosphorous results in the leaves turning brown accompanied by small leaves, weak stem and slow development. In olden days, the use of animal manures to provide phosphorous for plant growth was used as a common agricultural practice. Organically bound phosphorous enters in soil through the decay of natural vegetation, dead animals and from animal excretions. The role of micro flora on soil fertility was hardly understood. Assimilation of phosphate from organic compounds by plants and microorganisms take place through the enzyme "phosphatase" which is produced by in microorganisms. Phosphate can be absorbed by plants only in soluble form which is available in very less amount in soil. The transformation of insoluble phosphate into soluble form is done by several microbes present in the soil. A large fraction of soil 
microbes can dissolve insoluble inorganic phosphates present in the soil and make them available to the plants. There is high population of microorganisms are present in fertile soil and they are ubiquitous and at the same time highly proliferating. Rhizospheric bacteria can improve plant growth by utilizing diverse mechanisms including phosphate solubilization, phytohormone production, nitrogen fixation and bio-control of plant pathogens (Bhattacharyya and Jha, 2011; Vessey, 2003). A single plant growth promoting rhizobacterium (PGPR) may possess one or more than one of these plant beneficial traits (Vessey, 2003).

PGPR are important for agriculture as best alternative to chemical fertilizers due to the fact that application of PGPR as biofertilizer reduces the cost of crop production. A large number of PGPR like Azospirillum, Azotobacter, Bacillus, Enterobacter, Pseudomonas, Klebsiella and Paenibacillus has been isolated from rhizosphere of various crops (Saharan and Nehra, 2011; Vessey, 2003). Application of PGPR as biofertilizer has resulted in improved growth and grain yield of various crops such as wheat, rice, maize and sugarcane (Bhattacharyya and Jha 2011; Moutia et al., 2010; Saharan and Nehra 2011; Mirza et al., 2001). The use of plant growth promoting rhizobacteria, including phosphate solubilizing bacteria (PSB), as biofertilizers has become of interest in developing countries as significant areas of cultivated soils are deficient in soil available $\mathrm{P}(\mathrm{Xie}$ et al., 1998). As $\mathrm{P}$ is major essential macronutrients for plant growth and development, it is commonly applied to crops as fertilizer for optimizing the yield. PSB have been used to convert insoluble rock P material into soluble forms available for plant growth (Nahas,., D.A 1990; Bojinova et al., 1997). This conversion is through acidification, chelation and exchange reactions by PSB present in the soil. Phosphate Solublizing microbes are considered as important members of PGPR and their application in the form of biofertilizer has been shown to improve growth of cereals and other crops (Bhattacharyya and Jha 2011; Gyaneshwar et al., 2002; Hu et al., 2006; Shahab et al., 2009; Vessey 2003). Another mechanism utilized by PGPR for plant growth improvement is production of phytohormones (Saharan and Nehra 2011; Shahab et al., 2009; Vessey 2003). Plant growth hormones like auxins play a vital role in plant growth promotion by increasing root area and enhancing uptake of water and nutrients. Production of plant growth hormones like IAA is a major property of soil microorganisms including Azospirillum, Azotobacter, Bacillus, Enterobacter and Pseudomonas (Bhattacharyya and Jha 2011; Vessey 2003). Bacillus species is known for its ability to solubilize rock P material. The objective of the current study was the isolation of phosphate solubilizing bacteria from the rhizosphere of paddy, as well as the identification of the isolates for effective usage as biofertilizer for $\mathrm{P}$ nutrition in rice production.

\section{MATERIALS AND METHODS}

\section{1. Collection of soil samples}

The field sites for collecting soil sample to isolate PSM were selected randomly based on soil types, rice variety and cropping pattern under costal agriculture area of cuddalore district, Tamilnadu, India. Soil samples were collected from the rhizospher of rice randomly during the stage of standing crop. The soil samples were shady dried, powdered and transported to laboratory for further study. 


\section{2. Isolation of Phosphate Solublizing Bacteria (PSB)}

One gram of fine powdered soil sample was dispersed in $9 \mathrm{ml}$ of sterilized distilled water and rinsed thoroughly for 5mins. From this first dilution $1 \mathrm{ml}$ was transferred to $9 \mathrm{ml}$ of sterile distilled water to form $10^{-2}$ dilution. Similarly $10^{-3}, 10^{-4}, 10^{-5}$ and $10^{-6}$ dilutions were made for each soil sample. $0.1 \mathrm{ml}$ from $10^{-4}, 10^{-5}$ and $10^{-6}$ dilutions was taken by sterile pipette and transferred to in Petri-dishes containing sterilized and cooled Sperber (1958) medium (containing glucose $10.0 \mathrm{~g}$, yeast extract $0.5 \mathrm{~g}, \mathrm{Ca}_{3}\left(\mathrm{PO}_{4}\right)_{2} 2.5 \mathrm{~g}, \mathrm{CaCl}_{2} 0.1 \mathrm{~g}, \mathrm{MgSO}_{4}$ $7 \mathrm{H}_{2} \mathrm{O} 0.25 \mathrm{~g}$ and agar $15.0 \mathrm{~g}$ in one liter of distilled water with $\mathrm{pH}$ of 7.2) and incubated at 27 $-30{ }^{\circ} \mathrm{C}$ for 7 days. Colonies showing halo zones were picked and purified further using same medium and maintained in nutrient agar (Lapage et al., 1970) (containing Beef extract $3.0 \mathrm{~g}$, Peptone $5.0 \mathrm{~g}, \mathrm{NaCl} 5.0 \mathrm{~g}$, Agar $15.0 \mathrm{~g}$ in $1000 \mathrm{ml}$ distilled water with $\mathrm{pH}$ of 7.2) slants and preserved under refrigerated $\left(4^{\circ} \mathrm{C}\right)$ condition for further study.

\section{3. Colony and halo-zone diameter and solubilization index of PSB isolates}

Sterilized Sperber agar medium was poured in to sterilized Petri plates, after solidification of media; a pin point inoculation of PSB isolates were made on plates individually under aseptic conditions (Fig. 1). The inculcated Petri plated were incubated at $28{ }^{\circ} \mathrm{C}$ for 5-7 days. The diameter of bacterial colony and halozone was measured and the values were used for calculating solubilization index by following the formula SI = Colony diameter + Halozone diameter / Colony diameter (Edi-Premono, 1996).

\section{IDENTIFICATION OF PSB}

\section{1. Colony and Cell Morphological Characterization}

Colony and cell morphological futures of bacterial isolates were observed by culturing PSB isolates after 48 hours of spreading on Sperber agar medium in Petri plates. The cell capsule staining, cell motility, spore formations were observed for their characterization as prescribed by Lal et al., 2002. A loop full of bacterial culture was transferred on glass slide with a drop of sterile water and observed under light microscope (Vincent 1970) for recording cell morphology.

\section{2. Biochemical tests}

Biochemical tests such Indole production test, Citrate utilization test, Methyl red test, Voges Proskauer test, Oxidation fermentation test, Catalase test, Starch hydrololysis test, Nitrate reduction test, Casine production test and Gas production from glucose were performed to identify the bacterial isolates as suggested by Garrityet et al., (2004).

\section{3. Quantification of Phosphorus solubilization by PSB isolates}

The available phosphorous was determined by phospho-molybdate blue colour method (Murphy \& Riley, 1962). Sperber broth was prepared and poured $100 \mathrm{ml}$ in $250 \mathrm{ml}$ flasks and flasks were sterilized at $121{ }^{\circ} \mathrm{C}$ for 20 minutes and cooled to room temperature. A loop full of isolated PSB culture was inoculated to flasks individually under aseptic condition and placed on rotary shaker for 7 days. The suspension was centrifuged at $10000 \mathrm{rpm}$ for 15 minutes to remove bacterial cells and other insoluble materials. The available phosphorous was determined using spectrophotometer at $882 \mathrm{~nm}$ and calibrated with standard $\mathrm{KH}_{2} \mathrm{PO}_{4}$ curve. The quantity of available phosphorous in suspension was a measure of extent of solubilization of tricalcium phosphate by inoculated PSB isolates. 


\section{RESULTS AND DISCUSSION}

Bacterial colonies were confirmed as phosphate solubilizing bacteria (PSB) by observing holozone around the bacterial colony on Sperber agar medium and the colonies were transferred to nutrient agar slant and maintained in refrigerated condition for further characterization. A total of fifteen PSB isolates were selected based on maximum to minimum of holo-zone formation around the colonies for Identification, characterization in phosphate solubilization. The isolated phosphate solubilizing bacterial colonies were designated as $\mathrm{P}$ with serial number 1 to I5 (Table 1). Colonies of all the PSB isolates were round and creamy in colour. The observation of bacterial cell of all the PSB isolates under light microscope confirmed cell shape as bacilli except P9 and P12 which were Cocobacilli. The characteristics futures of PSB isolates such as spore production, cell motility and colouring of cell capsule were found as positive. But there was positive and negative result in other biochemical test performed for all the PSB isolates. Indole production test was positive with isolates P4,P6,P7,P11 and P14 while other isolates were not positive to Indole production.

All the PSB isolates showed positive in citrate utilization test except P1,P9, P10 and $\mathrm{P} 14$. In concerned with methyl red test, the PSB isolates P1,P3,P6,P8,P9,P10 and P12 exhibited positive result. Among the fifteen PSB isolates P1, P2,P10 and P12 showed negative result to oxidase test. But except $\mathrm{P} 14$ all the isolates were positive in catalase test while starch hydrolysis test was negative with five isolates namely P2,P,5,P7,P11 and P15. Among the PSB isolates P4,P6, P8, P9, P10, P12 and P13 showed positive to nitrate reduction. In concerned with casein hydrolysis, except $\mathrm{P} 2$ and $\mathrm{P} 13$ all the isolates exhibited positive result. Gas production test was positive only with isolates P7 and P10 while other isolates were negative to gas production test. Colony morphological and biochemical characters of all the bacterial isolates showed the characteristic features of typical bacillus species. Among the various rhizosphere associated bacteria Bacillus megaterium is probably the most studied and appear to have significant potential for commercial application as biofertilizer (Baumforth et al., 1999). Hence, the present finding is also an agreement to reports of Baumforth et al.

When grown in solid culture media supplemented with tricalcium phosphate, all the isolates produced holozone around the colonies indiagating the solubilization of phosphate source used. Phosphate solubilizing bacteria are detected by the formation of clear holozone around their colony. The phosphate solubilizing efficiency of isolated PSB was observed using culture media supplemented with tricalcium phosphate (Table 2). The maximum colony diameter was found with P6 $(1.91 \mathrm{~mm})$ and minimum was in P8 $(0.61 \mathrm{~mm})$. Similarly, P6 isolate showed maximum of holozone diameter $(5.89 \mathrm{~mm})$ and P8 exhibited lowest of 2.1 $\mathrm{mm}$ holozone. All the isolates were confirmed for the phosphate solubilizing ability by phosphate molybdate test. Phopho-molybdate test for quantidative determination of available phosphorous indicated that the isolated P6 solubilized significantly higher phosphate than all other PSB isolates. The phosphate solubilizing efficiency of PSB isolates was ranked as $\mathrm{P} 6>\mathrm{P} 1>\mathrm{P} 12>\mathrm{P} 3>\mathrm{p} 10>\mathrm{P} 11>\mathrm{P} 4>\mathrm{P} 2>\mathrm{P} 9>\mathrm{P} 7>\mathrm{P} 14>\mathrm{P} 8>\mathrm{P} 5>\mathrm{P} 15>\mathrm{P} 13$.

The phosphate solubilizing activity is determined by the microbial biochemical ability to produce and release organic acids, which through the carboxylic groups chelate the cations bound to phosphate converting them in to the soluble form (Kpombalekou and Tabatavai, 1994; Glick, 1995). The findings of the present study is also being reaffirmed that the phosphate solubilization by different PSB is involved with the production organic acid (Fasim et al.,2002; Rashid et al., 2004). 
Table 1. Morphological and Biochemical Characterization of PSB isolates from rhizosphere soil of rice.

\begin{tabular}{|c|c|c|c|c|c|c|c|c|c|c|c|c|c|c|c|}
\hline Test & $\mathrm{P} 1$ & $\mathrm{P} 2$ & $\mathrm{P} 3$ & $\mathrm{P} 4$ & $\mathrm{P} 5$ & $\mathrm{P} 6$ & $\mathrm{P} 7$ & $\mathrm{P} 8$ & $\mathrm{P} 9$ & $\mathrm{P} 10$ & $\mathrm{P} 11$ & $\mathrm{P} 12$ & $\mathrm{P} 13$ & $\mathrm{P} 14$ & $\mathrm{P} 15$ \\
\hline $\mathrm{CP}$ & $\mathrm{bc}$ & $\mathrm{bc}$ & $\mathrm{Bc}$ & $\mathrm{bc}$ & $\mathrm{bc}$ & $\mathrm{bc}$ & $\mathrm{Bc}$ & $\mathrm{bc}$ & $\mathrm{cb}$ & $\mathrm{Bc}$ & $\mathrm{Bc}$ & $\mathrm{Cb}$ & $\mathrm{bc}$ & $\mathrm{bc}$ & $\mathrm{bc}$ \\
\hline $\mathrm{SF}$ & + & + & + & + & + & + & + & + & + & + & + & + & + & + & + \\
\hline $\mathrm{CM}$ & + & + & + & + & + & + & + & + & + & + & + & + & + & + & + \\
\hline $\mathrm{GS}$ & + & + & + & + & + & + & + & + & + & + & + & + & + & + & + \\
\hline $\mathrm{IP}$ & - & - & - & + & - & + & + & - & - & - & + & - & - & + & - \\
\hline $\mathrm{CU}$ & - & + & + & + & + & + & + & + & - & - & + & + & + & - & + \\
\hline $\mathrm{MR}$ & + & - & - & + & - & + & - & + & + & + & - & + & - & - & - \\
\hline $\mathrm{VP}$ & + & + & + & + & + & + & + & + & + & + & + & + & + & + \\
\hline $\mathrm{OT}$ & - & - & + & + & + & + & + & + & + & - & + & - & + & + \\
\hline $\mathrm{CT}$ & + & + & + & + & + & + & + & + & + & + & + & + & + & - \\
\hline $\mathrm{SH}$ & + & - & + & + & - & + & - & + & + & + & - & + & - & + \\
\hline $\mathrm{NR}$ & - & - & - & + & - & + & - & + & + & + & - & + & + & + \\
\hline $\mathrm{CH}$ & + & - & + & + & + & + & + & + & + & + & + & + & - & + \\
\hline $\mathrm{GP}$ & - & - & - & - & - & - & + & - & - & - & + & - & - & - \\
\hline $\mathrm{CP}-$
\end{tabular}

CP- Cell Shape, SF- Spore Formation, CM- Cell Motility, GS- Gram Staining, IP- Indole Production, CUCitrate utilization, MR - Methyle red, VP - Voges - Proskauer, OT- Oxidase test, CT- Catalse test, SH- Starch hydrolysis, $\mathrm{NR}$ - Nitrate reduction, $\mathrm{CH}$ - Casin hydrolysis, GP - Gas production from glucose

$(+)$ - Positive, (-)- Negative, bc - bacilli, cb -Coco bacilli

Table 2. Phospate solubizing efficiency of PSB isolates from rhizosphere soil of rice.

\begin{tabular}{|c|c|c|c|c|c|c|c|c|c|c|c|c|c|c|c|}
\hline Test & $\mathrm{P} 1$ & $\mathrm{P} 2$ & $\mathrm{P} 3$ & P4 & P5 & P6 & P7 & P8 & P9 & P10 & P11 & P12 & P13 & P14 & P15 \\
\hline $\begin{array}{c}\mathrm{CD} \\
(\mathrm{mm})\end{array}$ & $\stackrel{0}{-}$ & $\stackrel{?}{2}$ & $\vec{\beth}$ & $\begin{array}{l}\text { ț } \\
0\end{array}$ & 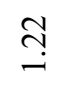 & $\bar{\sigma}$ & $\stackrel{\text { I. }}{-}$ & $\stackrel{\vec{b}}{0}$ & กี & $\stackrel{\infty}{-}$ & 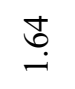 & 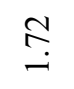 & $\begin{array}{l}n \\
\stackrel{0}{0} \\
0\end{array}$ & $\stackrel{\infty}{n}$ & $\begin{array}{l}\infty \\
\stackrel{0}{0} \\
0\end{array}$ \\
\hline $\begin{array}{l}\text { HD } \\
(\mathrm{mm})\end{array}$ & $\begin{array}{l}\infty \\
\stackrel{\infty}{+}\end{array}$ & $\stackrel{\alpha}{\sigma}$ & $\hat{n}$ & $\frac{n}{i}$ & 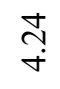 & $\begin{array}{l}\infty \\
\dot{\infty} \\
\dot{1}\end{array}$ & $\hat{n}$ & $\stackrel{\circ}{\stackrel{1}{i}}$ & $\begin{array}{l}\stackrel{\infty}{+} \\
\text { in }\end{array}$ & $\hat{m}$ & $\begin{array}{l}\tilde{n} \\
\text { in }\end{array}$ & $\begin{array}{l}\infty \\
\dot{b} \\
\dot{n}\end{array}$ & $\stackrel{\infty}{\vec{i}}$ & $\stackrel{\wp}{\stackrel{+}{+}}$ & $\begin{array}{l}\infty \\
\stackrel{\infty}{i} \\
i\end{array}$ \\
\hline SI & $\vec{F}$ & $\underset{+}{\stackrel{N}{*}}$ & $\stackrel{尺}{\stackrel{\gamma}{+}}$ & $\stackrel{+}{+}+\underset{+}{+}$ & $\begin{array}{l}n \\
i n \\
+\end{array}$ & $\stackrel{\infty}{\stackrel{+}{+}}$ & $\begin{array}{l}\hat{\sigma} \\
\dot{+}\end{array}$ & $\underset{+}{\stackrel{\forall}{*}}$ & $\begin{array}{l}8 \\
\dot{+}\end{array}$ & $\underset{\forall}{\vec{F}}$ & 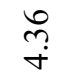 & 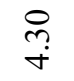 & $\begin{array}{l}n \\
\dddot{n} \\
\dot{r}\end{array}$ & in & $\underset{+}{\stackrel{+}{+}}$ \\
\hline $\begin{array}{c}\mathrm{AP} \\
(\mu \mathrm{g} / \mathrm{ml})\end{array}$ & $\begin{array}{l}\tilde{N} \\
\stackrel{i}{N} \\
\sim\end{array}$ & $\begin{array}{l}\overrightarrow{6} \\
\stackrel{n}{n}\end{array}$ & 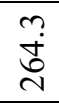 & $\begin{array}{l}0 \\
\infty \\
\infty \\
i\end{array}$ & $\begin{array}{l}n \\
\tilde{n} \\
\tilde{n}\end{array}$ & $\stackrel{\vec{\pi}}{n}$ & $\stackrel{\sim}{\tilde{H}}$ & $\stackrel{m}{\tilde{n}}$ & 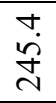 & $\begin{array}{l}\text { mi } \\
\text { W }\end{array}$ & 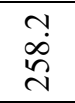 & $\begin{array}{l}0 \\
\stackrel{\sim}{N} \\
\stackrel{v}{v}\end{array}$ & ָָ̀ & $\underset{\substack{\dot{J}\\
}}{\infty}$ & 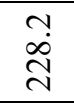 \\
\hline
\end{tabular}

Data represents mean value of three determinations 


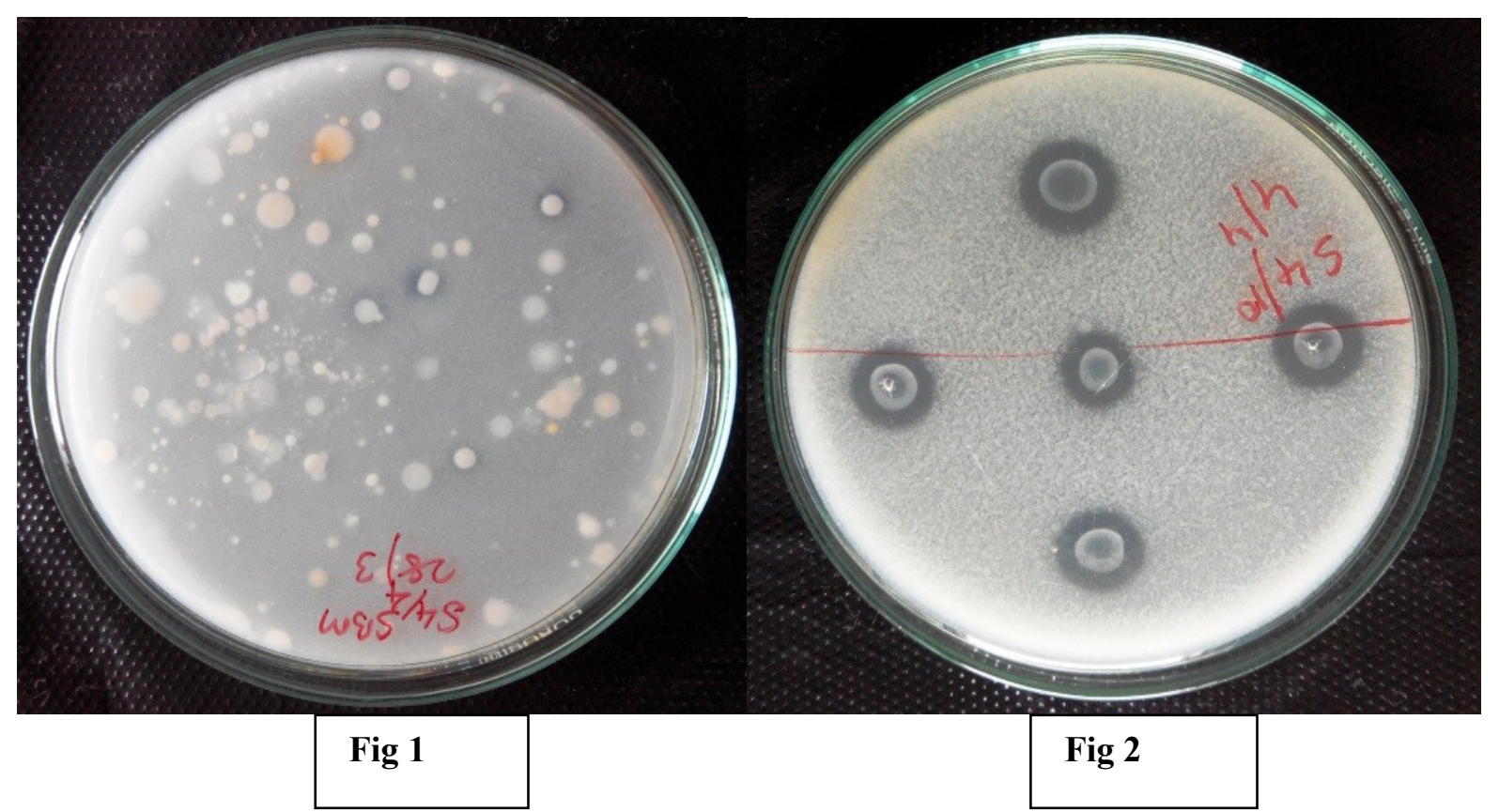

CD-Colony diameter, HD-Holo Zone diameter, SI - Solubiliztaion index, AP - Available Phosphorous

\section{CONCLUSION}

The colony morphological and biochemical characterization of isolated PSB confirms all the isolates as bacillus species. However, identification of isolated PSB strains is required on the basis of molecular techniques. It is inferred from the results that PSB isolate P6 was more efficient in terms of phosphate solubilization by holozone formation as well as in increasing available phosphorous in growth medium which supplemented with tricalcium phosphate. As phosphate solubilizing bacteria can be used as biofertilizers for crops, the new PSB isolate P6 can be considered as effective PSB for paddy cultivation. Even though, the PSB isolate P1 showed high efficiency in phosphate solubilization in vitro, it should be further field tested for confirmation. Modern agricultural practices largely rely on high inputs of mineral fertilizers to achieve high yield. The present research is very necessary to improve soil condition on environmentally friendly agriculture that is being practiced at present.

\section{Acknowledgement}

The authors gratefully acknowledge University Grant Commission, Government of India for providing the financial assistance to accomplish this investigation through sanctioning research grant under major research project.

\section{Reference}

[1] Baumforth K. R. N., et al., Mol. Pathol. 52 (1999) 1-10.

[2] Bhattacharyya P., Jha D., World J Microb Biot. 28 (2011) 1327-1350.

[3] Bojinova D., R. Velkova, I. Grancharov, S. Zhelev., Nutr. Cyc. Agroecosyst. 47 (1997) 227-232. 
[4] Cook, K ., Microbial inoculation in agriculture. Shell Agriculture,(1990) 9: $22-25$.

[5] Fasim F., Ahmed N., Parson R., Gadd, G. M., FEMS Microbiol. Lett. 213 (2002) 1-6.

[6] Glick B. R., Can. J. Microbiol. 41 (1995) 109-117.

[7] Kpomblekou K., Tabatabai M. A., Soil Sci. 158 (1994) 442-453.

[8] Lal, L., In: Agrotech Pub. Academy, Udaipur, p. 224, (2002).

[9] Lapage S., Shelton J. and Mitchell T., Methods in Microbiology, Norries J and Ribbons D., (Eds)., (1970) Vol.3 A, Academy Press, London.

[10] Moutia J. F. Y., Saumtally S., Spaepen S., Vanderleyden J., Plant Soil. 337 (2010) 233242.

[11] Murphy J., J. R. Riley, Analytica Chimica Acta 27 (1962) 31-36.

[12] Nahas E., D. A. Banzatto L.C. Assis., Soil Biol. Biochem. 22 (1990) 1097-1101.

[13] Rashid M., Khalil S., Ayub N., Alam S., Latif F., Pak. J. Biol. Sci. 7 (2004) 187-196.

[14] Saharan B., Nehra V., Life Sci Med Res. 21 (2011) 1-30.

[15] Sambrook J., Fristch E. F., Maniatis T., Molecular cloning: A laboratory manual 2nd edition CSH laboratory press (1989) Vol. I, Section 6.

[16] Vessey J. K., Plant Soil 255 (2003) 571-586.

[17] Vincent J. M., A Manual for the practical study of Root-Nodule Bacteria, Blackwell Scientific, Oxford. I.B.P Handbook, (1970) 15.

[18] Xie J. C., Plant Nut. Fer. Sci. 4 (1998) 321-330. 